\title{
実験技術
}

\section{二光子顕微鏡を用いた脳の in vivo イメージング}

\section{鍋倉 淳一，江藤 圭}

要約: 従来のイメージング技術では生きた動物の内部 で起きている現象をサブミクロンの解像度でとらえる ことは困難であった. 2 光子顕微鏡はこのような生体 現象を捉えることができる強力なツールとして注目を 集めている. そこで, 本稿では 2 光子顕微鏡の動作原 理, 特徵と, この顕微鏡を用いた in vivo イメージング 応用例について紹介する. 2 光子顕微鏡の動作原理で ある 2 光子励起過程は対物レンズの焦点でのみ起きる ため, また, 近赤外光を用いるため, 低侵襲性で組織 深部の構造物を観察することができる. 2 光子顕微鏡 はこのような特殊な励起過程を誘導するために必要な フェムト秒パルスレーザーや外部光路を有している. また, 大脳皮質の構造物の in vivo イメージングを行う ためには動物に対し, 観察空の形成手術（頭蓋骨を薄 く削る thin skull 法，または頭蓋骨を取り除く cranial window 法) を行う必要がある。 それぞれの手術法に は長所と短所があるため, 目的によって手術法を使い 分ける必要がある. 観察密を作成した動物に 2 光子顕 微鏡を適用し, 神経細胞やグリア細胞の in vivo 形態イ メージングや，カルシウムイメージングを用いた機能 イメージングなどを紹介する.

\section{1. 背景}

認知・行動やその発達などの脳機能発現・変化の背 景には, 神経細胞やそのネットワークの形態・機能の 経時的変化が起こっていることが予想される. 脳機能 発現の基盤を理解するために機能的核磁気共鳴法 (fMRI) やポジトロン断層法 (PET) などの非侵襲的 生体イメージングが盛んに用いられている。しかし, これらのイメージング法は時間・空間解像度が低く, また，血流変化など間接的なものを指標とするため, 神経ネットーワークやその構成単位という微細構造の
形態・機能の生体内抽出は困難であった。一方，バイ オイメージングの領域で広く用いられている共焦点顕 微鏡は空間分解能に優れている. しかし, 深部到達度 は組織表面から数十ミクロンが限界であり，また，し ばしば組織・細胞に対する侵襲性が問題である。また, 生体から取り出した標本から得られた情報は, 生体内 の形態・機能としばしば一致せず, ライフサイエンス 分野での大きな壁となっていた。このように従来の技 術では，生きた動物の内部での“あるがまま”の状態 の細胞や微細構造の形態や機能を, 高い時空間分解能 で観察することは困難であり, in vitro の標本から得ら れた情報をもとに生体脳内で起きている現象を推測す るしか手がなかった．従来の研究手法の持つ問題点を 克服する有力な手段として 2 光子顕微鏡が近年注目さ れている.この顕微鏡を用いることによって, 生体組 織内で起きているダイナミックな現象をサブミクロン レベルの解像度で捉えることができるようになった。

\section{2 光子顕微鏡の動作原理とその特徵}

\section{1） 2 光子励起とは}

1 光子励起の場合, 1 個の蛍光分子が 1 個の光子の 持つエネルギーを受け取ることにより, 蛍光分子内の エネルギーレベルが基底状態から第一次電子励起状態 へと遷移する.一方, 2 光子励起は, 1 光子励起の場合 に比べて, 理論的に半分のエネルギーを持つ光子（波 長でいえば 2 倍波長の光子) が 2 個ほぼ同時に 1 個の 蛍光分子にエネルギーを渡すことで起きる励起過程で ある（図 1)。1 個の光子が 1 個の蛍光分子と相互作用 する場合に比べて, 2 個の光子が同時に蛍光分子と相 互作用する確立はきわめて低い，そのため， 2 光子励 起の効率を上げるためには, 高密度の光子領域を作り 出す必要がある. 


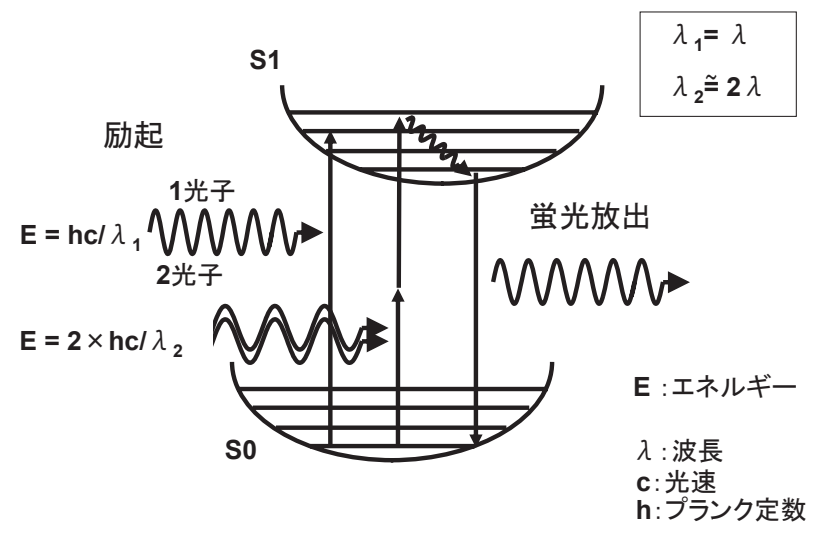

図 12 光子励起過程

\section{2）2 光子励起の特徵}

2 光子顕微鏡の光源として, チタンサファイアレー ザーなどの, フェムト秒パルスレーザーを使用する. このレーザーは共焦点顕微鏡で使用される連続発振レ ーザーと異なり, パルス状に発振し, 対物レンズ下に レーザー光を集光し，瞬間的（フェムト秒）に極めて 光子密度の高い領域を作ることができる，このため， 2 光子励起現象は対物レンズの焦点でのみ起きる（励 起の局所性）（図 2)。そのため, 共焦点顕微鏡のよう に焦点以外で生じた蛍光をピンホールにより取り除く 必要がなく, 組織深部で散乱した蛍光成分も像を形成 するために利用することができる，連続発振レーザー を用いて同様の光子密度領域を作成することも可能だ が, 効率が悪く, 1 光子励起が広い領域で起きてしま うため, 生物標本がダメージを受けてしまう。一方で, 2 光子顕微鏡では, フェムト秒パルスレーザーを用い て焦点のみで蛍光分子を極短時間励起することで熱に よる組織傷害も減少するため, 長時間観察も可能であ る(低侵襲性)（図 2)。また，組織内での散乱吸収が 少ない近赤外光を励起光として使用するため, 組織の
より媣部まで光が到達できる（高い透過性）（図 2）. さらに, 1 光子励起では深部組織を観察しようとする と浅層の蛍光分子に励起光が吸収されてしまうため深 部まで光が届きにくくなる. 2 光子励起は局所におい てのみ起きるためこのような励起光の減衰が起きにく い(自己遮蔽効果の回避)。これらの利点により, 2 光 子顕微鏡を用いることで, 生体組織の深部の微細構造 を長期間観察することが可能となった.

\section{In vivo 2 光子イメージングのための装置}

\section{1）外部光路}

2 光子顕微鏡と共焦点顕微鏡の違いの一つとして外 部光路が必要な点が挙げられる. 2 光子顕微鏡はその 外部にレーザー光を顕微鏡まで誘導する光路が常設さ れており，この光路は 2 つの特徵的な装置を有する (図 3)。一つはチャープ補正システムである。フェム 卜秒光パルスはミラーやレンズなどの媒質を通過する と, 波長の短い成分が長い成分より先行し（ポジティ ブチャープ), パルス幅が増加してしまう． 2 光子励起 はパルス幅が短いほど効率よく起きるため，このずれ を補正（ネガティブチャープを付与）する必要がある. この補正を光学的に行うためのプリズム, チャープ補 正系が外部光路に設置されている。もも一つの特徵的 な装置はビームエキスパンダーである。この装置は, 対物レンズのバックアパーチャーの径を満たすように 励起光を導入するために用いられ，これにより，顕微 鏡の分解能を最大限に引き出すことができる. 我々は, いくつかの光路径の独自の改良を行っている.

\section{2) 検出器}

2 光子顕微鏡では前述の通り, 生じた蛍光成分を全 て像の形成に使うことができる，そのため，できるだ け蛍光の損失を防ぐために光電子増倍管（PMT）は可 能な限り対物レンズの近傍に置くことが理想的である.

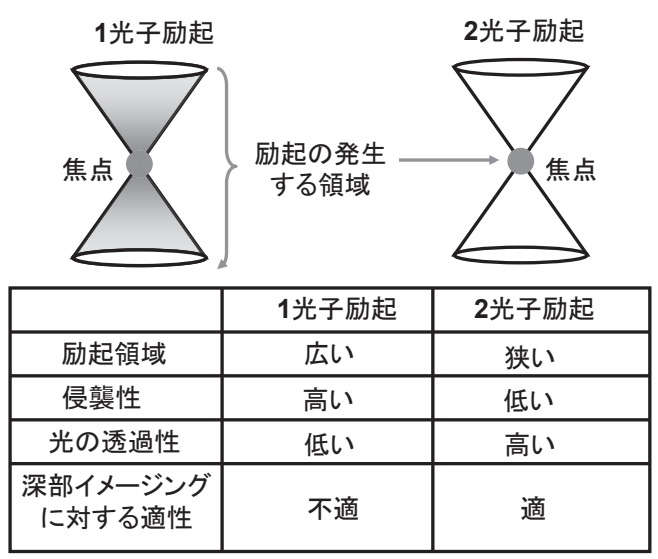

図 21 光子励起と 2 光子励起の比較

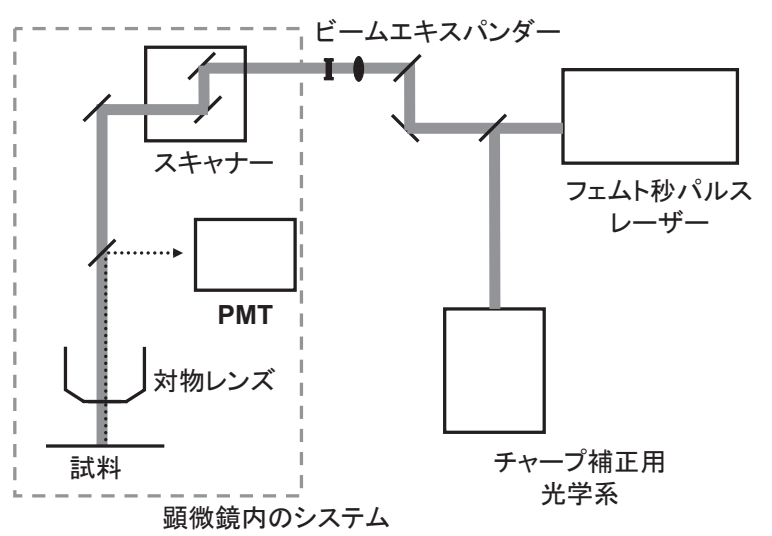

図 32 光子顕微鏡システムの例 


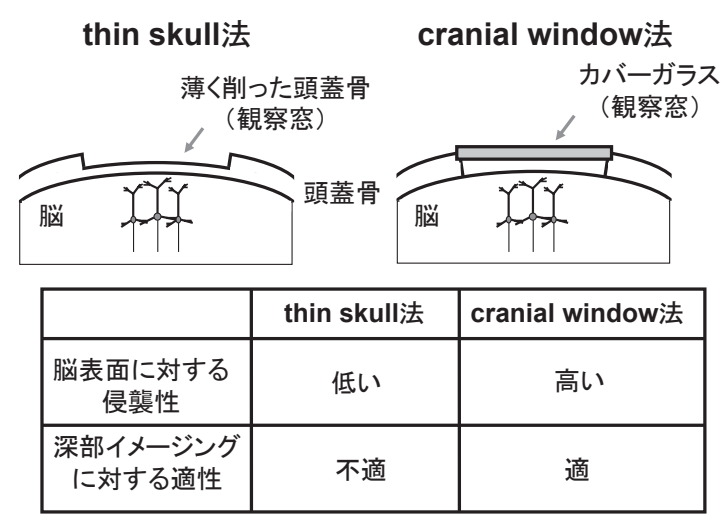

図4 In vivo イメージング用の手術法

\section{In vivo 2 光子イメージングのための動物手 術法}

2 光子顕微鏡を用いた in vivo イメージングを行うた めの主な手術法として, 頭蓋骨を残す方法（thin skull 法）と，頭蓋骨を取り除く方法（cranial window 法） の 2 種類がある（図 4)。前者の手法は頭蓋骨を薄く削 り 20-40 $\mu \mathrm{m}$ の厚さの骨を残すことで観察密を作成す る.この方法は, 頭蓋骨を取り除かないため, 脳表面 の組織に対して与えるダメージを抑えることができる という利点を持つ。しかし, 骨が残っているため脳組 織深部の構造物・活動のイメージングには不向きであ り，また，骨再生などにより観察回数が限られる，ダ メージによって容易に活性化してしまう脳内免疫細胞 であるミクログリアのイメージングや, 大脳皮質表層 にある樹状突起やスパイン構造のイメージングに適し た手術法である。一方で, cranial window 法は, 頭蓋 骨を取り除いた後, カバーガラスで置換する. カバー ガラスと脳の間はアガロース, あるいは人工脳脊髄液 を充填する。この方法は, 脳深部の構造物の観察に適 している．脳表面の組織に対して多少ダメージを与え るという久点はあるが, 繰り返し観察が可能ため, 脳 の深部構造物を数力月以上も観察する際にはこの方法 が適している. また, 観察領域への直接薬物投与や電 極挿入などの脳内アプローチを伴う実験にも適してい る. 生体イメージングの問題となるのは, 心拍, 呼吸, 体動や固定に伴う振動である. この振動を抑える方法 として, 我々は, 特殊リングを頭蓋骨観察空に取り付 けるとともに, カバーガラスの下にアガロースを充填 することで物理的に脳を押さえている.

\section{In vivo 2 光子イメージングの応用例}

ここまで述べてきた 2 光子顕微鏡を用いた生きたマ ウス個体のイメージングに関する例を紹介する.

\section{1）大脳皮質第 5 層錐体細胞の微細構造の in vivo イメ ージング}

大脳皮質第 5 層錐体細胞に蛍光タンパク質（yellow fluorescent protein: YFP) が発現している遺伝子改変 マウスにおいて，頭蓋骨をカバーガラスに置換した後， マウス個体の大脳皮質深部の神経細胞の微細構構造を 観察した（図 5)。第 5 層錐体細胞の細胞体，そして basal dendrite, apical dendrite 拈よび大脳皮質表面に 延びる樹状突起, シナプス構造（スパイン）を観察す ることができた．現在，皮質表面から $0.9 \mathrm{~mm}$ 以上の 深部における微細構造をサブミクロンの解像度を保っ たまま観察することが可能である。このことは，脳深 部のスパインや軸索などの神経細胞の微細構造を立体 的に捉えることができることを示している.さらに, 2 光子顕微鏡の低侵襲性により, 脳深部の神経微細構 造を同一個体に打いて, リアルタイム観察や長期的に 繰り返し観察することができる（図 6)。これにより， スパインやブートン構造などのシナプス微細構造の短 時間および長期間にわたる経時的構造変化を観察する ことが可能である。長期間の繰り返し観察では，脳表 面の血管による 2 次元的マッピングや最初のイメージ ングで得られた $Z$ 軸情報の他に, 周辺にある血管や特 徵的な細胞構造を指標として目的構造物を繰り返し探 しだす. 現在では数カ月間の長期間繰り返しイメージ ングにも成功している。 この手法により, 発達期, お よび障害時における神経回路編成を観察することが可 能である。

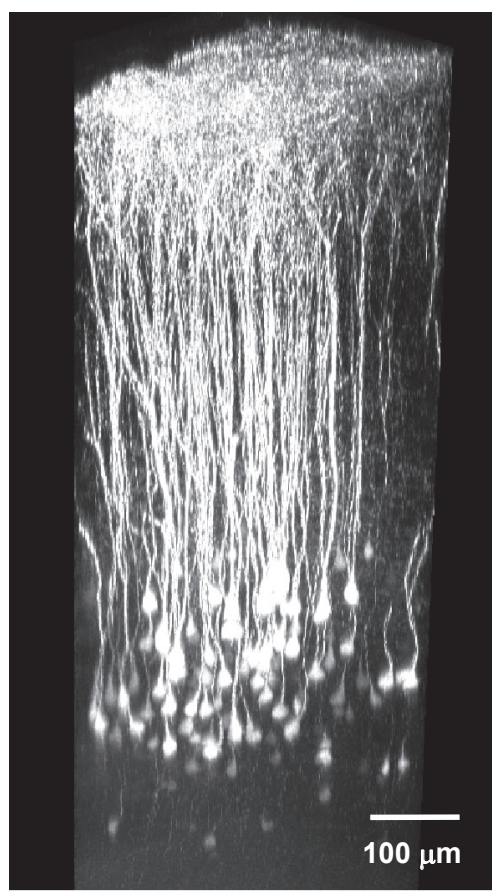

図 5 大脳皮質第 5 層錐体細胞の in vivo イメージング 
Day 0

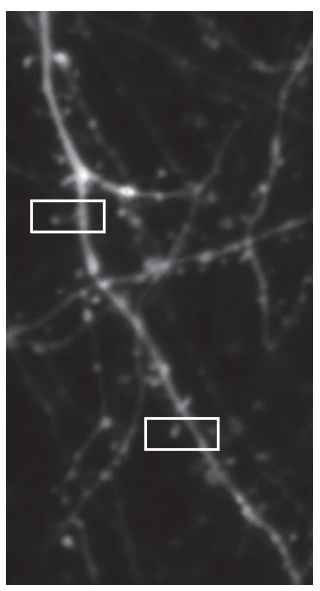

Day 3

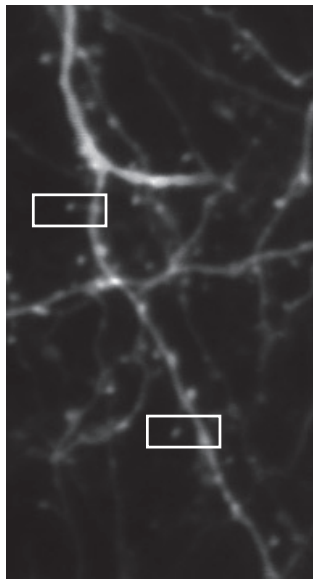

Day 15

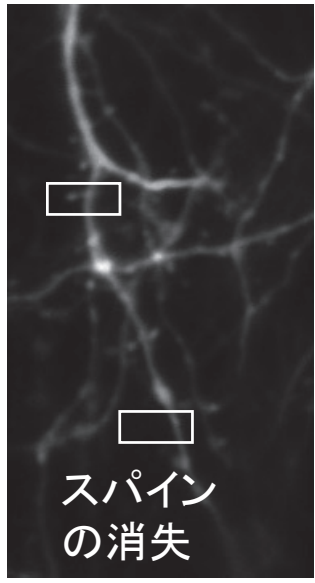

Day 21

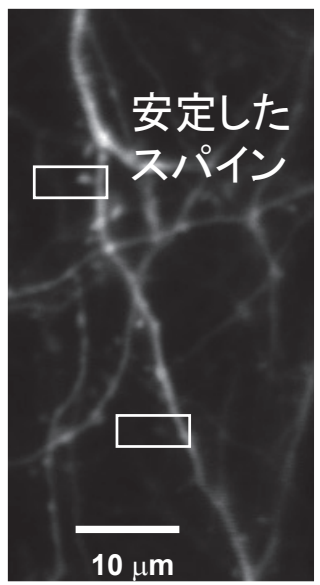

図 6 脳深部微細構造の長期 in vivo イメージング
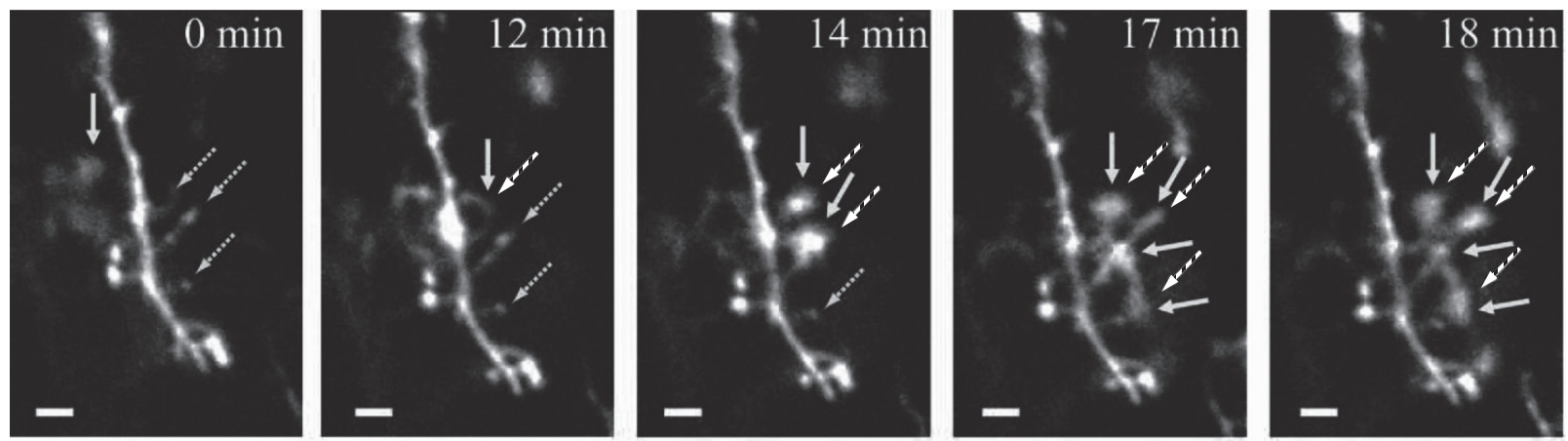

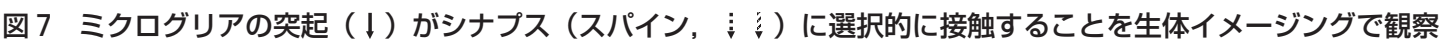

2）様々な微細構造物のイメージング

2 光子顕微鏡は蛍光タンパク質を発現している遺伝 子改変動物や蛍光色素と組み合わせることで脳内の 様々な構造物を観察することができる．例えば，グリ ア細胞の一つであるミクログリアと神経細胞が EGFP で標識されている遺伝子改変マウスを用いることで, ミクログリアと神経細胞の生体内でのダイナミックな 動きを捉えることができる(1）（図 7)。ミクログリア は培養系やスライス標本を用いてよく調べられている が, in vitro 標本では容易に活性化してしまうため, 正 常時のミクログリアの性質を調べるためには生きた動 物での観察が不可欠である.さらに, cranial window 法のために頭蓋骨を取り外すことによっても活性化す るという報告 (2) もあり，この細胞の観察の際には細 心の注意を払い頭蓋骨を薄く削る thin skull 法が最適 である，正常脳ではミクログリアの突起がシナプスを 選択的に 1 時間毎に 5 分間接触監視していることが観 察できた，梗塞周囲ペナンブラ領域においてはミクロ グリアのシナプス接触時間が 1 時間以上延長するとと もに，シナプスを包括するような接触様式にかわり，
しばしば障害シナプスの消失（除去）を惹起すること が生体リアルタイムイメージングを用いることで初め て観察することができた。このような蛍光タンパク質 を発現させた遺伝子改変動物を用いた微細構造観察だ けでなく, 蛍光色素を用いて染色した脳内構造物の観 察を行うことができる．例えば，グリア細胞の一つで あるアストロサイトは sulforhodamine 101 によって選 択的に染色されることが知られている(3)。アストロ サイト細胞体やその突起の endfootが脳血管に巻きつ いている像も捉えることができる，さらに，蛍光色素 を用いた in vivo イメージングのもう一つの例として 微小血管の観察がある. 未梢の静脈（尾静脈など）か ら蛍光色素を注入することにより，脳微小血管を染色 することが可能である(4)，さらに血中を流れる血球 成分が黒い影として観察できるため，この影の動く速 度をイメージングによって捉えることにより，微小血 管の血流を捉えることも可能である(4). また, 投与 した蛍光色素の動態を定量化することにより，毛細血 管における血流の定量化が可能である. 
3） 2 光子顕微鏡を用いた in vivo カルシウムイメージ ング

2 光子顕微鏡は微細構造およびその動態の観察だけ でなく, Oregon Green 488 BAPTA-1 AM や fluo-4 AM, fura-2 AM などのカルシウム蛍光指示薬を利用するこ とにより, 神経細胞活動のイメージングにも用いるこ とができる. カルシウム蛍光指示色素を充填した微小 ガラス管を脳内に挿入し, 弱い圧力により序々に脳内 に投与することにより，神経細胞を染色する．この手 法を用いることにより, 生きた動物の脳内の神経活動 をカルシウム応答として捉えることができる．さらに， 複数の神経細胞の活動を同時に捕らえることができる ため, 脳機能マッピングを調べる手段としても有効で ある(5).

4）ケージド試薬などの光感受性化合物を用いた非侵

\section{襲的刺激法}

2 光子顕微鏡は構造や機能の観察だけでなく, 刺激 のためのッールとしても使用できる. 光感受性のケー ジド試薬を 2 光子顕微鏡で励起すると, 限局した領域 においてのみケージド試薬を活性化させることが可能 となる。この手法を用いることで，スライス標本でス
パインのような微細構造物のみをケージドグルタミン 酸などで刺激 (6) することや，ケージドカルシウムを 用いたアストロサイト細胞 (7) や神経細胞の刺激も可 能である．また，Cali 法などと組み合わせると細胞内 局所における機能タンパク質の活性制御や, 特定細胞 への光による遺伝子導入が可能となることが期待出来 る.

\section{6. おわりに}

この様に 2 光子顕微鏡を用いた in vivo イメージン グにより，脳内の様々な細胞の微細構造，機能を観察 できるだけでなく，光を用いた非侵襲的刺激による活 動操作を組み合わせることで，今後，生体での未知の 現象が次々に明らかになると期待できる.

\section{文献}

1) Wake H, et al. J Neurosci. 2009 Apr 1;29 (13):3974-3980.

2) Xu HT, et al. Nat Neurosci. 2007;10 (5):549-551.

3) Nimmerjahn A, et al. Nat Methods. 2004 Oct;1 (1):31-37.

4) Schaffer CB, et al. PLoS Biol. 2006 Feb;4(2):e22.

5) Ohki K, et al. Nature. 2005 Feb10;433 (7026):597-603.

6) Matsuzaki M, et al. Nat Neurosci. 2001 Nov;4(11):1086-1092.

7) Takano T, et al. Nat Neurosci. 2006 Feb;9 (2):260-267.

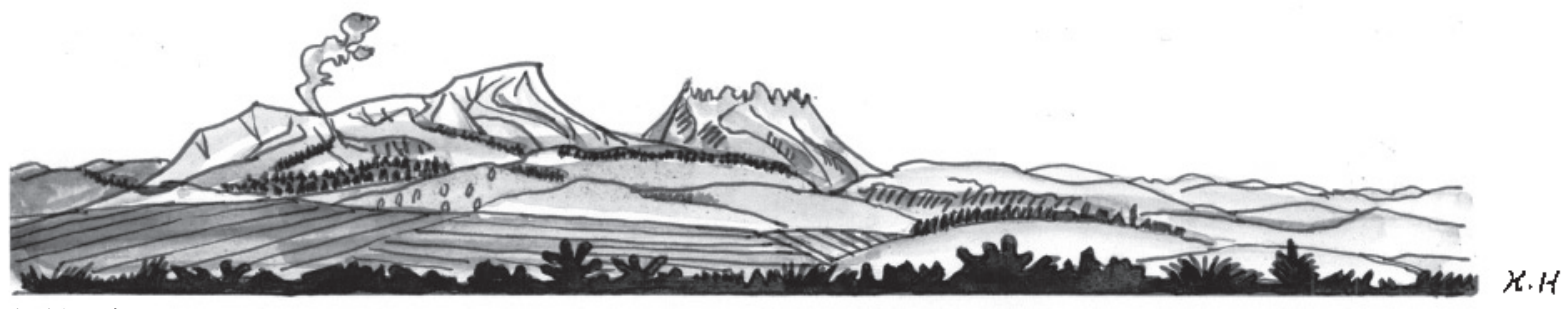

風景・春 